\title{
EFFECTS OF URBAN DEVELOPMENT IN MICROCLIMATIC CONDITIONS IN THESSALONIKI
}

\author{
KOSMOPOULOS P. \\ KANTZIOURA A.
}

\author{
Laboratory of Environmental and \\ Energy Efficient Design of Buildings and Settlements \\ Department of Environmental Engineering \\ Democritus University of Thrace \\ Vas. Sofias 12, Zip Code 67100, Xanthi, Greece
}

Received: 01/10/2012

Accepted: 01/10/2014

Available online: 02/10/2014

*to whom all correspondence should be addressed: e-mail: pkosmos@env.duth.gr

\section{ABSTRACT}

The urban planning, the buildings and covering materials of all surfaces, the distance between adjacent constructions, the height and the orientation of the buildings are some of the factors which affect the sustainable conditions in the city.

This paper presents a project that aims at investigating the influence of urban developments in microclimatic conditions. The purpose of the research is to investigate how the characteristics of built environment contribute the microclimatic conditions. The investigation was carried out in the urban center of Thessaloniki, Greece The urban geometry, the position and the height of the building inside the urban canyon, the orientation are factors that influence the surface temperature and microclimatic conditions (air temperature, wind speed, wind direction). The results of the investigation could contribute at the urban planning and the sustainable development of the contemporary cities.

Keywords: urban microclimate, urban heat islands, urban geometry

\section{Introduction}

The increasing rate of cities' growth has caused the deterioration of urban environment (Kosmopoulos, 2008). Deficiencies in development control have important consequences to the urban climate and to the environmental efficiency of buildings. These have as a result changes in the heat balance and higher air temperatures in the densely built urban areas than the temperatures of the surrounding country and the appearance of the urban heat island (UHI) phenomenon (Santamouris, 2001).

The heterogeneity of the urban form and the form of buildings influence the micro-scale climate. A most widely used model to describe the effect of urban geometry to microclimate is the urban canyon. Urban canyon refers to a linear space such as a street which is bounded on both sides by vertical elements such as the walls of adjacent buildings. One of the terms that describe the geometry of an urban canyon is the ratio height of buildings/width of road (H/W), known as aspect ratio, which refers to the sectional proportions of the urban canyon (Erell et al., 2011). It is observed that inside the urban canyons the microclimatic conditions, such as the wind speed and direction, are modified according to the morphological characteristics and meteorology of the surrounding area (Andreou and Axarli, 2012).

The research was carried out in Thessaloniki, which is the second largest city in Greece. The summer period is characterized by high temperature, low relative humidity and precipitation with northerly 
prevailing winds. In particular, the average temperature for July is $27.3^{\circ} \mathrm{C}$ with an absolute maximum of $41.8^{\circ} \mathrm{C}$ and a minimum of $14.4^{\circ} \mathrm{C}$ (Stathopoulou et al., 2004).

Previous studies on urban environment using satellite (Stathopoulou et al., 2004) or ground data (Mihalakakou et al., 2004) have shown that the urban heat island of Thessaloniki is well-known and of comparative intensity; night-time UHI intensity can reach up to $8^{\circ} \mathrm{C}$ (Stathopoulou et al., 2004). The UHI intensity between the central urban and surrounding rural areas of the city is estimated about of 2.7$4^{\circ} \mathrm{C}$. Suburban areas appear to be $1.2^{\circ} \mathrm{C}$ cooler than the central urban areas and $1.5^{\circ} \mathrm{C}$ warmer than the surrounding rural areas (Mihalakakou et al., 2004). The urban zone of Thessaloniki is heated more quickly and effectively than the suburban surroundings, especially in early morning hours (Giannaros et al., 2010).

According to previous research paper (Kantzioura et al., 2012), the surface temperatures on July, of the buildings' envelope are lower in the floors which are above to fourth floor and the maximum temperatures are measured at the ground (glass façade) and first floor. Also, from the comparison between the measured microclimatic data on $1,5 \mathrm{~m}$ and from the meteorological data of greater Thessaloniki area, it was presumed that the geometry of the streets affects the creation of different microclimatic conditions in the urban canyons.

In the present study, the fluctuation of surface temperature in May, July and August are investigated according to the orientation and the heights. Also, the differences of air temperature inside the urban canyons, between the study area, the surroundings and the greater area during winter, spring and summer period are analyzed.

\section{Methodology}

The study area is in the densely residential and commercial center of the city and it can be regarded as an area with typical geometrical characteristics. The measurements period took place in two procedure cycles, which are described below.

\subsection{Description of the experimental area}

A number of measurements were organized in a crossway of four streets at Mitropoleos and Agias Sofias Street. The streets' length is from $50 \mathrm{~m}$ to $100 \mathrm{~m}$ and the height of the buildings is about $21 \mathrm{~m}$ (Table 1).

Table 1. Geometric characteristics of each street

\begin{tabular}{ccccc}
\hline \multirow{2}{*}{ Orientation } & Avg Height, $\mathrm{H}(\mathrm{m})$ & Avg Length, $\mathrm{L}(\mathrm{m})$ & Avg. Width, W $(\mathrm{m})$ & $\mathrm{H} / \mathrm{W}$ \\
\hline West & 23 & 60 & 12.5 & 1.8 \\
\hline North & 21 & 70 & 14 & 1.4 \\
\hline East & 21 & 100 & 14 & 1.5 \\
\hline South & 18 & 50 & 14 & 1.3 \\
\hline
\end{tabular}

The four examined roads are constituted by blocks in each site and in the ground floor of each building there are stores of commercial use and their façade are just windows.

The measurement points in each study street are shown in Fig 1 . The West and North streets are regarded as urban canyons with high buildings in both sides of the road. In the Wast and North streets, there is a lower height building, which affects the sunlight and the shadow to each building during the day. 

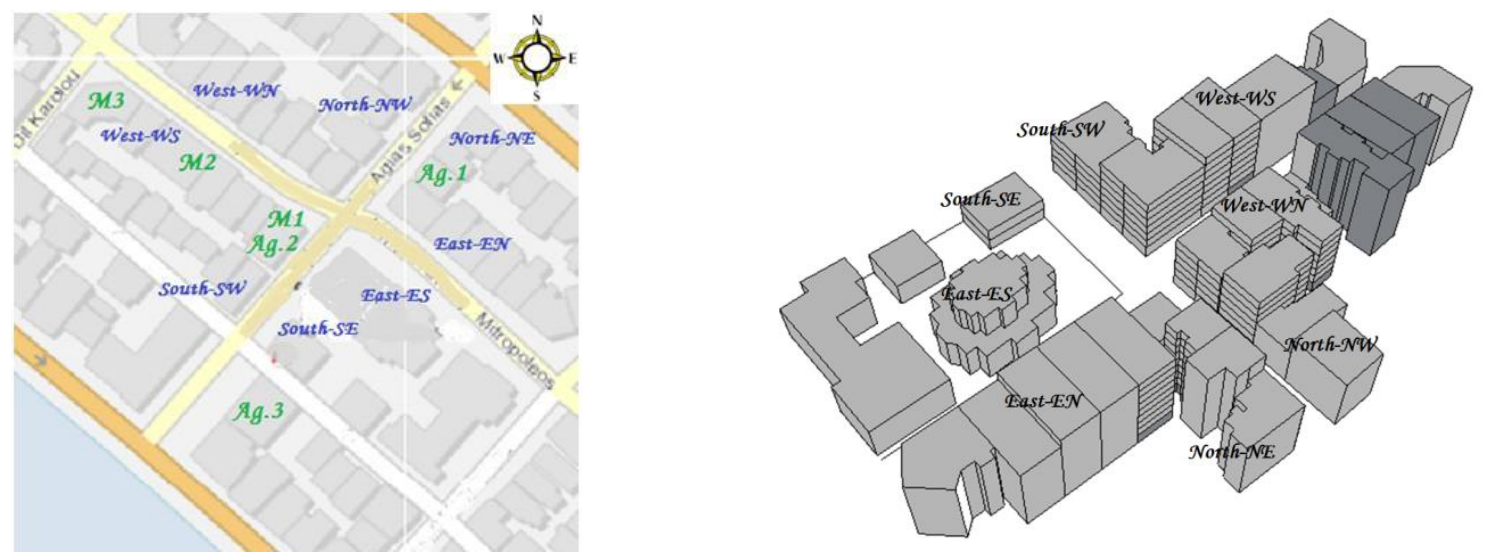

Figure 1. The study area of measurements' experimental procedures

\subsection{Experimental procedure}

The aim of the present study is to investigate the microclimatic conditions inside the canyons and the thermal behavior of the buildings' envelopes. It focuses to the urban geometry, surface temperatures and microclimatic parameters, so as to observe the effect of urban configuration in microclimatic conditions in the urban centre.

The field surveys involved surface temperature measurements by a thermal camera and microclimatic monitoring with portable mini-weather stations. The experimental measurement procedures include two different operation programs.

During the first program, the surface temperatures of the buildings were measured by using thermography, as previous studies (Kantzioura et al., 2012). For each floor and building the average surface temperature is estimated for each measurement period and it analyzes the thermal behavior according to the orientation and the urban geometry. Each building has been considered separated in two vertical parts (left and right), so as to have more detailed and precise observation during the measures. Therefore, for the description of the field experiments the name e.g. "Building1/2" represents the first building in the street, but it refers to the second vertical part (right part) of the same building.

The air temperature has been measured on a height of $1,5 \mathrm{~m}$, at the centre of the street, at each orientation. The height of $1,5 \mathrm{~m}$ was selected in order to monitor the microclimatic conditions in pedestrians' level. The surface temperature and air temperature were measured on an hour basis. Each point was monitored for 12-hours (8:00-20:00), to get the daily pattern of the surface temperature fluctuation. The field surveys took place in May, July and August.

Table 2. The abbreviation of each measurement point

\begin{tabular}{cccc}
\hline No of Building & Street & Height of measurement & Abbreviation \\
\hline $\mathbf{1}$ & Agias Sofias & $4 \mathrm{~m}$ & $4 \mathrm{Ag} 1$ \\
\hline $\mathbf{1}$ & Agias Sofias & $16 \mathrm{~m}$ & $16 \mathrm{Ag} 1$ \\
\hline $\mathbf{1}$ & Agias Sofias & $25 \mathrm{~m}$ & $25 \mathrm{Ag} 1$ \\
\hline $\mathbf{2}$ & Agias Sofias & $4 \mathrm{~m}$ & $4 \mathrm{Ag} 2$ \\
\hline $\mathbf{2}$ & Agias Sofias & $7 \mathrm{~m}$ & $7 \mathrm{Ag} 2$ \\
\hline $\mathbf{2}$ & Agias Sofias & $22 \mathrm{~m}$ & $22 \mathrm{Ag} 2$ \\
\hline $\mathbf{3}$ & Agias Sofias & $4 \mathrm{~m}$ & $4 \mathrm{Ag} 3$ \\
\hline $\mathbf{1}$ & Mitropoleos & $4 \mathrm{~m}$ & $4 \mathrm{M} 1$ \\
\hline $\mathbf{1}$ & Mitropoleos & $22 \mathrm{~m}$ & $22 \mathrm{M} 1$ \\
\hline $\mathbf{2}$ & Mitropoleos & $4 \mathrm{~m}$ & $4 \mathrm{M} 2$ \\
\hline $\mathbf{3}$ & Mitropoleos & $7 \mathrm{~m}$ & $7 \mathrm{M} 3$ \\
\hline
\end{tabular}


The second program included continuous measurement of microclimatic parameters and specifically the air temperature (T), the wind speed (WS) and the wind direction (WD). The mini weather stations for monitoring the air temperature were placed in 5 specific fixed Measurements Points (MP) in the study area. The weather stations were placed in different heights along the two main streets.

On Table 2, the abbreviation of each measurement point is indicated. For example, the abbreviation $16 \mathrm{Ag} 1$ is referred to the measurement point which located in the first (1) examinated building, along to the Agias Sofias Street (Ag), on $16 \mathrm{~m}$ height.

Also, data from two local meteorological stations were used to compare the air temperature of the Greater Thessaloniki Area (GTA) and of a neighborhood area. The meteorological data from GTA come from the area near to the Airport. The urban-rural locations chosen are often located in the central business district of a city and at the airport (Gartland, 2008). The elevation of the Airport area is about $4 \mathrm{~m}$ and the distance from the urban center of Thessaloniki is $14,6 \mathrm{~km}$. Also, as regard the meteorological data of the neighborhood, there is a meteorological station of the Municipality Thessaloniki at Benizelou Street, in about $500 \mathrm{~m}$ distance from the study area. This operation program includes measurements that conducted in February, April, May, June and July.

\section{Results and discussion}

A statistical analysis of the collected data was carried out. The discussion below presents the results and observations as they came out from the study.

\subsection{Surface temperatures of buildings' envelope and microclimatic conditions}

On the West side, for all floors, the observed maximum surface temperature during May is at 14:00h, for both sides of the road (Fig. 2). In August, the surfaces reach up the maximum temperature one hour after, at 15:00h. During July, except from the max temperature during midday time at 14:00 to 15:00, it is observed a momentary peak at morning, 10:00h, to the first buildings of the crossway. As regards the buildings inside the urban canyon, they reach the maximum temperature hours later, at 20:00h, during July afternoon (Fig. 3).

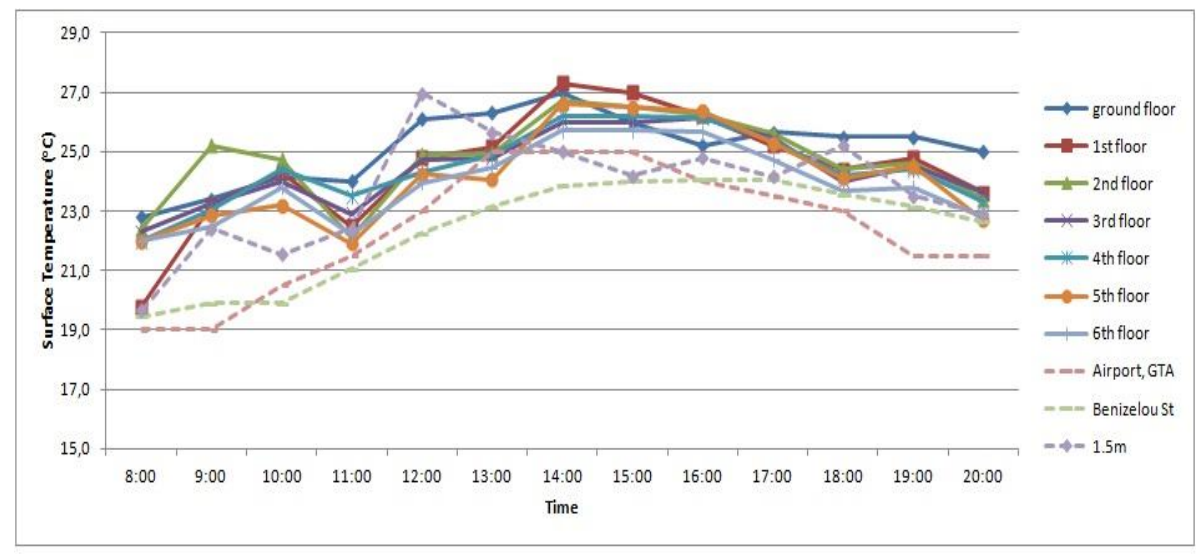

Figure 2. Maximum surface temperature during May at 14:00h, Building 1/1, West-WS side.

On the North road, the surface temperatures are higher at the first floors of the corner buildings during all day, while the surface temperatures of the buildings inside the canyon are higher at the first floors in morning and higher at the last floors during afternoon. Also, a peak at surface temperatures at 11:00 is observed, on both two sides. The maximum temperature on North-NE side is observed at 18:00h and after it is gradually decreasing, while on the North-NW side the surface temperature is decreasing after 11:00h. It is conducted that in northern street, the orientation of the sides of the road cross, affects the thermal behavior of the vertical surfaces. The orientation and the sun's position result to the fluctuation of surface temperatures. So, in the western side of the road, which is exposed to the solar radiation 
during morning time, the maximum $\mathrm{T}_{\text {surf }}$ is observed at 11:00am. On the other hand, in the eastern side of the road the maximum surface temperature appears at afternoon, at sunset.

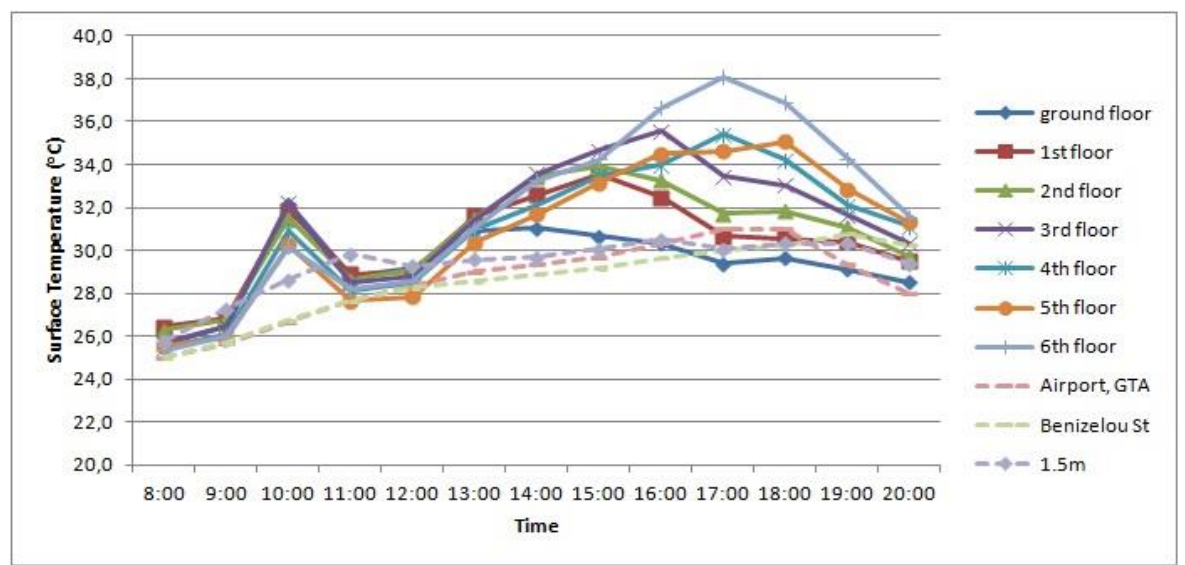

Figure 3. Buildings facade inside the urban canyon, which reaches the maximum temperature at 20:00h during July afternoon, Building 2/1, West-WN side.

On the East road, at the site opposite to the low height building (East-EN), the maximum surface temperature is at 19:00 during July and at 17:00 during August. In the side East-ES, the maximum temperature is observed two hours earlier. The first floors have the maximum temperatures during the experiment measurement period (Fig. 4).

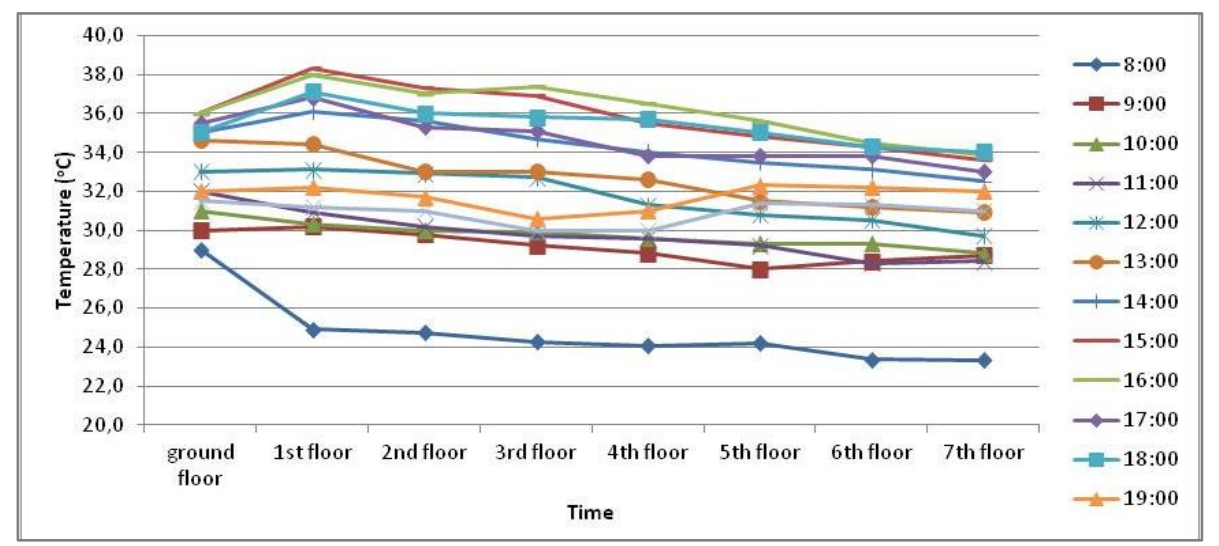

Figure 4. Maximum temperatures in the first floors during the experimental measurement period, Building 2/1, East-EN side, August

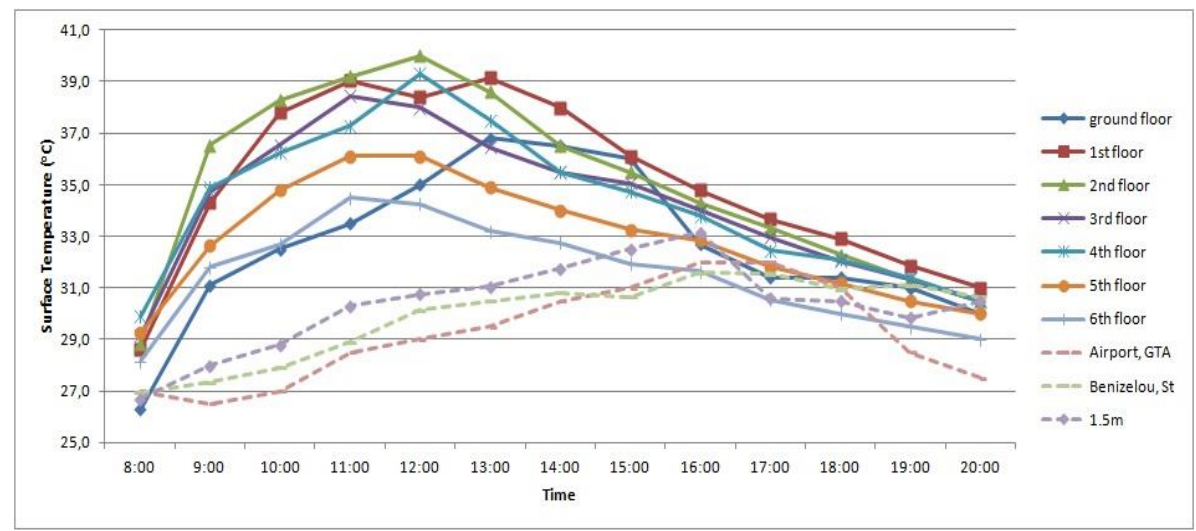

Figure 5. Maximum surface temperatures at 11:00 to 12:00a.m. and decreasing during the next hours, Building 1/1, South-SW, August. 
On the South-SE side the maximum surface temperatures are observed at 17:00 to 18:00h, while on the other side during the morning time, at 11:00 to 12:00a.m. Then the temperature is decreasing. The first floors are characterized by higher temperatures than the last floors (Fig 5).

Also, it is observed that the air temperature during the experimental procedures is higher at pedestrians' level $(1.5 \mathrm{~m})$ in the four streets, than in the suburban area (Airport weather station) and of the neighborhood area (GTA). In the GTA the air temperature is measured at $43 \mathrm{~m}$ height.

The maximum surface temperatures for each orientation, the time and the height that they are observed are given in Table 3. The surface temperatures in streets with North-South orientated axis have different thermal behavior between the two opposite sites. In the North-W and South-W site, the maximum surface temperatures have been observed during the morning time, while in the North-E and South-E site they have been observed during afternoon and they have lower values.

The maximum surface temperatures in streets with West-East orientated axis have beeb observed mainly during afternoon. Neither site of the road (West-N or West-S, East-N or East-S) influences the thermal behavior of the vertical surfaces, as it has been observed in South-North axis. The time period of the maximum values in West Street, are between 14:00pm-16:00pm and in the East Street are between 17:00pm-18:00pm.

Table 3. The time of maximum surface temperature for each orientation

\begin{tabular}{|c|c|c|c|c|c|c|c|c|c|c|}
\hline & & \multicolumn{3}{|c|}{ Building 1/1 } & \multicolumn{3}{|c|}{ Building 1/2 } & \multicolumn{3}{|c|}{ Building 2/1 } \\
\hline & & Time & $\begin{array}{c}\mathrm{T}_{\text {surface }} \\
\left({ }^{\circ} \mathrm{C}\right)\end{array}$ & Floor & Time & $\begin{array}{c}\mathrm{T}_{\text {surface }} \\
\left({ }^{\mathrm{C}} \mathrm{C}\right)\end{array}$ & Floor & Time & $\begin{array}{c}T_{\text {surface }} \\
\left({ }^{\mathrm{O}} \mathrm{C}\right)\end{array}$ & Floor \\
\hline \multirow{3}{*}{ West-S } & May & $14: 00$ & 27,3 & $1^{\text {st }}$ & $16: 00$ & 26,3 & $1^{\text {st }}$ & $14: 00$ & 26,4 & $1^{\text {st }}$ \\
\hline & July & $16: 00$ & 32 & $2^{\text {nd }}$ & $16: 00$ & 33,3 & $4^{\text {th }}$ & $14: 00$ & 32,1 & $4^{\text {th }}$ \\
\hline & August & $15: 00$ & 33,1 & $3^{\text {rd }}$ & $15: 00$ & 32,6 & $5^{\text {th }}$ & $14: 00$ & 33,4 & $1^{\text {st }}$ \\
\hline \multirow{3}{*}{ West-N } & May & $16: 00$ & 27,5 & $5^{\text {th }}$ & $14: 00$ & 30,1 & $2^{\text {nd }}$ & $14: 00$ & 32,1 & $6^{\text {th }}$ \\
\hline & July & $16: 00$ & 35,3 & $5^{\text {th }}$ & $17: 00$ & 38,6 & $5^{\text {th }}$ & $15: 00$ & 38,1 & $6^{\text {th }}$ \\
\hline & August & $16: 00$ & 38,3 & $5^{\text {th }}$ & $15: 00$ & 42,6 & $4^{\text {th }}$ & $15: 00$ & 39,6 & $6^{\text {th }}$ \\
\hline \multirow{3}{*}{ North-E } & May & & & & & & & & & \\
\hline & July & $18: 00$ & 34,7 & $2^{\text {nd }}$ & $17: 00$ & 34,9 & $2^{\text {nd }}$ & $18: 00$ & 33,4 & $3^{\text {rd }}, 8^{\text {th }}$ \\
\hline & August & $18: 00$ & 35,8 & $2^{\text {ond }}$ & $17: 00$ & 35,7 & $2^{\text {nd }}$ & $17: 00$ & 34,6 & $1^{\text {st }}$ \\
\hline \multirow{3}{*}{ North-W } & May & $11: 00$ & & & $11: 00$ & & & $12: 00$ & & \\
\hline & July & $10: 00$ & 36,6 & $5^{\text {th }}$ & $10: 00$ & 40,1 & $3^{\text {rd }}$ & $12: 00$ & 34,8 & $3^{\text {rd }}$ \\
\hline & August & $11: 00$ & 37,6 & $5^{\text {th }}$ & $11: 00$ & 40,3 & $2^{\text {nd }}$ & $11: 00$ & 35,8 & $5^{\text {th }}$ \\
\hline \multirow{3}{*}{ East-S } & May & & & & & & & & & \\
\hline & July & $16: 00$ & 31,7 & $2^{\text {nd }}$ & & & & & & \\
\hline & August & $18: 00$ & 33,3 & $1^{\mathrm{st}}$ & & & & & & \\
\hline \multirow{3}{*}{ East-N } & May & $16: 00$ & 28,9 & $1^{\text {st }}$ & $18: 00$ & 30,9 & $1^{\text {st }}$ & $18: 00$ & 28,3 & $1^{\text {st }}$ \\
\hline & July & $17: 00$ & 37,8 & $1^{\text {st }}$ & $17: 00$ & 37,8 & $2^{\text {nd }}$ & $17: 00$ & 35,7 & $3^{\text {rd }}$ \\
\hline & August & $16: 00$ & 40 & $1^{\text {st }}$ & $17: 00$ & 38,7 & $2^{\text {nd }}$ & $17: 00$ & 37,6 & $1^{\text {st }}$ \\
\hline \multirow{3}{*}{ South-E } & May & & & & & & & & & \\
\hline & July & 18:00 & 37,2 & $1^{\text {st }}$ & $17: 00$ & 32 & $\begin{array}{c}\text { Grou } \\
\text { nd }\end{array}$ & & & \\
\hline & August & $17: 00$ & 35,3 & Ground & $17: 00$ & 32,2 & $\begin{array}{c}\text { Grou } \\
\text { nd }\end{array}$ & $17: 00$ & 32,4 & $\begin{array}{c}\text { Groun } \\
\mathrm{d}\end{array}$ \\
\hline \multirow{3}{*}{ South-W } & May & $12: 00$ & 31,4 & $2^{\text {nd }}$ & & 29,5 & $2^{\text {nd }}$ & $11: 00$ & 28,1 & $2^{\text {nd }}$ \\
\hline & July & $10: 00$ & 40,6 & $1^{\mathrm{st}}$ & $10: 00$ & 37,2 & $3^{\text {rd }}$ & $10: 00$ & 38,2 & $1^{\text {st }}$ \\
\hline & August & $12: 00$ & 40 & $2^{\text {nd }}$ & $11: 00$ & 39 & $2^{\text {nd }}$ & $11: 00$ & 37,9 & $1^{\text {st }}$ \\
\hline
\end{tabular}




\subsection{Microclimatic and meteorological data of the city}

\subsubsection{Air Temperature}

During the second cycle of the measurements procedure, the air temperatures inside the urban canyons have been observed. According to the height where the mobile weather stations were placed and the distance from the crossway, the daily air temperature differences, from February to July are analyzed. For each month, the average value from all the days that measurements were carried out, has been used. The measurement points are located in Ag. Sofias Street and Mitropoleos Street. The weather stations were placed at different heights at the buildings: $4 \mathrm{~m}, 7 \mathrm{~m}, 16 \mathrm{~m}, 22 \mathrm{~m}$ and $25 \mathrm{~m}$ height. In each street, three different buildings along the canyon were chosen (Fig.1). In the diagrams below a specific symbolism is used. For example the symbolism $25 \mathrm{Ag} 1$ refers to the height of $25 \mathrm{~m}$, in the building Ag1, in Ag. Sofias Street (Fig.1).

In February (Fig. 6) the air temperature on $4 \mathrm{~m}$ height is higher than on $25 \mathrm{~m}$ to the building Ag.1, except from 15:00 to $17: 00 \mathrm{hrs}$ and on $16 \mathrm{~m}$ is higher than on $25 \mathrm{~m}$ with exception of 10:00 to 17:00hours. Also, at $4 \mathrm{~m}$ height the temperature is higher than in $16 \mathrm{~m}$, except for 18:00 to 20:00hrs. In the building Ag3 the temperature in $4 \mathrm{~m}$ is higher than at the building Ag1 during the night, and lower from 8:00 to 17:00hrs. The first building is nearest to the sea. During the day, it is concluded that inside the canyon there are higher air temperatures. This microclimatic characteristic is due to the urban morphology. The geometry of the area influences the air temperature and the street's ventilation and as a result, an increase of the air temperature is observed.

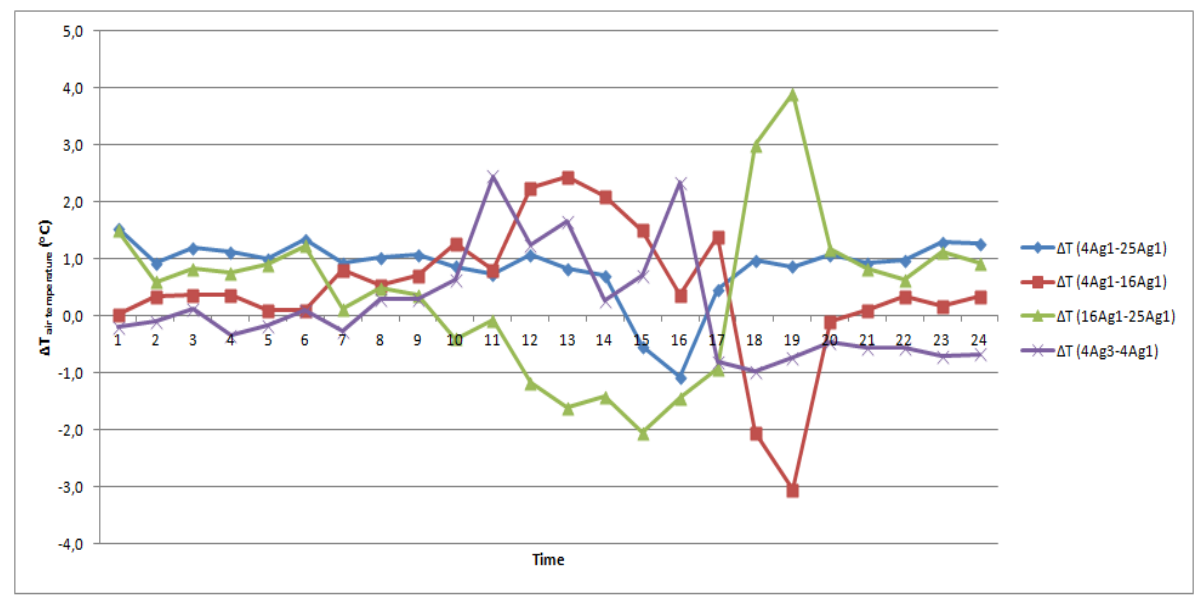

Figure 6. Air Temperatures in February, along the canyon of Ag.Sofias Street

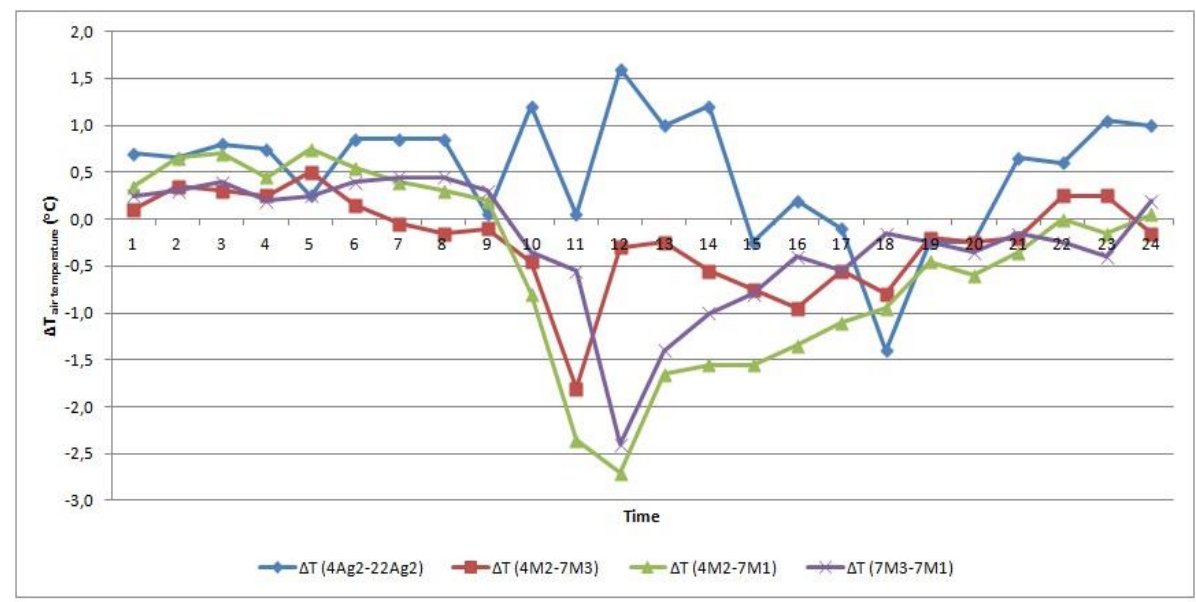

Figure 7. $\Delta \mathrm{T}$ of Air Temperatures in April, along the canyon of Mitropoleos Street and in building Ag2 
In April (Fig. 7), the air temperature at the building Ag.2 is higher at $4 \mathrm{~m}$ than at $22 \mathrm{~m}$, except from two hours between 18:00 to 20:00hrs. As regards the air temperature inside the canyon of Mitropoleos Street, it is higher at the building $M 1$ than in $M 2$ and M3 during the day from 10:00 to 23:00. The air temperature at the end of the canyon (building $\mathrm{M} 3$ ) is higher than in the middle (building M2), except for night hours.

In May, at Ag.Sofias Street the air temperature is higher at $4 \mathrm{~m}$ than at $25 \mathrm{~m}$ except for 10:00 to 15:00 and afternoon 17:00-21:00 hrs. Along the canyon, in the first building we observe higher temperatures than at the second, at the last floor. Also, at $4 \mathrm{~m}$ height the temperature is higher in the third building than at the first.

In June, the air temperature in Mitropoleos Street is higher at building M3, which is located in the end of the canyon, than at the building $M 2$, during all the day.

In July (Fig. 8), during the day (9:00-17:00hrs) the air temperature at $4 \mathrm{~m}$ in building Ag.1 is lower than in the building Ag.3. The temperature at Ag.3 is higher during afternoon and night (18:00-7:00hrs) than at Ag.2. Moreover, it is observed that the difference $\triangle T(4 \mathrm{Ag} 3-4 \mathrm{Ag} 1)$ is almost constant in comparison with $\triangle T(4 A g 3-4 A g 2)$. The measurement points $4 A g 3$ and $4 A g 1$ are alongside urban canyons, while the $4 A g 2$ is in the corner of the crossway. So, the location along the urban canyon constitutes an important factor effect.

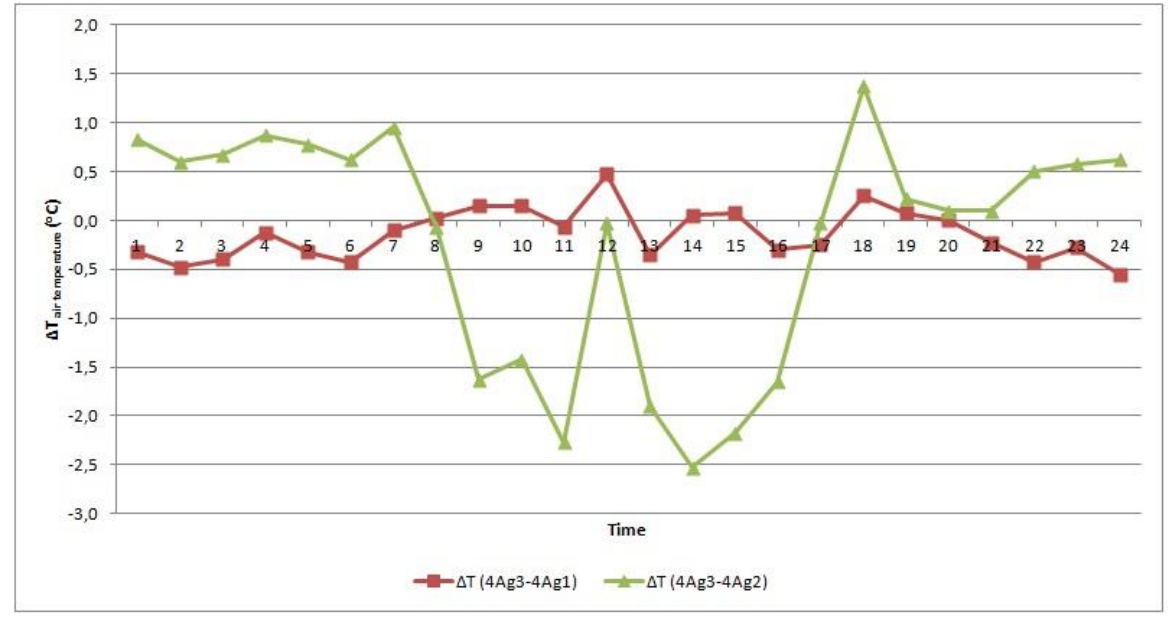

Figure 8. Air Temperatures in July, along the canyon of Ag.Sofias Street

So, it is concluded that the air temperature inside the urban canyons differs according the height and the position along the canyon. The morphology and the geometric characteristics of urban morphology in the study area are important factors. In Table 4, the results of the above analysis are summarized. For each month, the comparison of air temperature for the different measurement points, the mean difference between the two comparable measurements points and the time periods where the comparison isn't in valuable (exceptions) are given.

The average differences between the measurement procedures, which were carried out at 20:00pm and 8:00am, are summarized in Table 5 . In the urban center, the differences are greater than in the suburban area of the Airport (GTA). The air temperature in the urban study area, in pedestrian's level, remains higher during afternoon time in comparison to the $T_{\text {air }}$ in suburban area. The urban geometry and the morphological characteristics, such as the ratio $\mathrm{H} / \mathrm{W}$ of the urban canyon, affect the fluctuation of the air temperature. The small ratio, the restricted ventilation inside urban fabric and the absorbed and emitted heat from the structural surfaces have as a result the increasing of the $T_{\text {air }}$ during the day, the slower rate of temperature decreasing after sunshine and the greater differences of temperature between 8:00am and 20:00pm than in suburban area (GTA).

The maximum temperature difference has been observed in May $\left(7^{\circ} \mathrm{C}\right)$, inside the east orientated street in the urban center. 
Table 4. Comparison of Air Temperatures between different measurement points for each month

\begin{tabular}{|c|c|c|c|}
\hline Month & Air Temperature & $\begin{array}{l}\text { Mean differences between the two } \\
\text { comparable measurement points }\end{array}$ & Exceptions \\
\hline \multirow{4}{*}{ February } & 4Ag1 > 25Ag1 & $1.0^{\circ} \mathrm{C}$ & 15:00 pm-17:00 pm \\
\hline & 16Ag1 > 25Ag1 & $1.2^{\circ} \mathrm{C}$ & 10:00 am-17:00 pm \\
\hline & 4Ag1 > 16Ag1 & $0.8^{\circ} \mathrm{C}$ & $18: 00$ pm -20:00 pm \\
\hline & $4 \mathrm{Ag} 3>4 \mathrm{Ag} 1$ & $0.9^{\circ} \mathrm{C}$ & 8:00 am-17:00 pm \\
\hline \multirow{4}{*}{ April } & $4 \mathrm{Ag} 2>22 \mathrm{Ag} 2$ & $0.8^{\circ} \mathrm{C}$ & $18: 00$ pm -20:00 pm \\
\hline & $7 \mathrm{M} 1>4 \mathrm{M} 2$ & $1.2^{\circ} \mathrm{C}$ & 24:00 pm -9:00 am \\
\hline & $7 \mathrm{M} 1>7 \mathrm{M} 3$ & $0.6^{\circ} \mathrm{C}$ & 24:00 pm -9:00 am \\
\hline & $7 \mathrm{M} 3>4 \mathrm{M} 2$ & $0.5^{\circ} \mathrm{C}$ & 22:00 pm -6:00 pm \\
\hline \multirow{3}{*}{ May } & $4 \mathrm{Ag} 1>25 \mathrm{Ag} 1$ & $0.7^{\circ} \mathrm{C}$ & $\begin{array}{l}10: 00 \mathrm{am}-15: 00 \mathrm{pm} \\
17: 00 \mathrm{pm}-21: 00 \mathrm{pm}\end{array}$ \\
\hline & $25 \mathrm{Ag} 1$ > 22Ag2 & $0.8^{\circ} \mathrm{C}$ & 9:00 am-15:00 pm \\
\hline & $4 \mathrm{Ag} 3$ > 4Ag1 & $0.7^{\circ} \mathrm{C}$ & $16: 00 \mathrm{pm}-17: 00 \mathrm{pm}$ \\
\hline June & $7 \mathrm{M} 3>4 \mathrm{M} 2$ & $0.6^{\circ} \mathrm{C}$ & \\
\hline \multirow{3}{*}{ July } & $4 \mathrm{Ag} 3>4 \mathrm{Ag} 1$ & $0.1^{\circ} \mathrm{C}$ & 21:00pm-8:00am \\
\hline & $4 \mathrm{Ag} 3>22 \mathrm{Ag} 2$ & $0.5^{\circ} \mathrm{C}$ & 8:00am-17:00pm \\
\hline & $22 \mathrm{M} 1>22 \mathrm{Ag} 2$ & $0.9^{\circ} \mathrm{C}$ & 14:00pm-19:00pm \\
\hline
\end{tabular}

Instead, in August the temperature difference in suburban area, between the morning and afternoon measurement procedure, is small. This is due to the high temperatures through the day. Nonetheless, the $\mathrm{T}_{\text {air }}$ in pedestrian's level $(1.5 \mathrm{~m})$ appears great temperature differences, resulting in uncomfortable thermal conditions.

Table 5. Air Temperature Differences on 1.5m height (pedestrian's level) between 20:00pm and 8:00am

\begin{tabular}{|c|c|c|c|c|c|}
\hline & \multicolumn{4}{|c|}{ Urban Center } & \multirow[t]{2}{*}{ GTA } \\
\hline & West & North & East & South & \\
\hline May & $3,3^{\circ} \mathrm{C}$ & & $7,0^{\circ} \mathrm{C}$ & $3,3^{\circ} \mathrm{C}$ & $2.5^{\circ} \mathrm{C}$ \\
\hline July & $3,3^{\circ} \mathrm{C}$ & $2,7^{\circ} \mathrm{C}$ & $2,8^{\circ} \mathrm{C}$ & $3,1^{\circ} \mathrm{C}$ & $3,0^{\circ} \mathrm{C}$ \\
\hline August & $2,9^{\circ} \mathrm{C}$ & $3,6^{\circ} \mathrm{C}$ & $3,1^{\circ} \mathrm{C}$ & $3,8^{\circ} \mathrm{C}$ & $0.5^{\circ} \mathrm{C}$ \\
\hline
\end{tabular}

\subsubsection{Correlation between Surface Temperature $\left(T_{\text {surf }}\right)$ and Air Temperature $\left(T_{\text {air }}\right.$}

The correlation $\rho$ between $T_{\text {surf }}$ and $T_{\text {air }}$ is calculated and analyzed below. In Table 9, the correlation coefficients between $\mathrm{T}_{\text {air }}$ at pedestrians' level $(1.5 \mathrm{~m})$ and $\mathrm{T}_{\text {surf }}$ of each floor are given. The correlation of these two parameters is greater between the air temperature on $1.5 \mathrm{~m}$ height and surface temperature of the ground and first floor. On higher floors, less correlation with $\mathrm{T}_{\text {air }}$ in pedestrians' level is observed.

In May and August the $\rho$ is greater than July and it is estimated at 0.701 to 0.898 . The maximum values of coefficient have appeared in the urban canyon of North and West street, where there are high buildings on both sides of the road.

So, in the western and northern urban canyon an increase of the vertical surface temperature on ground and first floor in observed when the air temperature at pedestrians' level is increasing. It is concluded that the urban geometry of the built environment affects the urban microclimate inside the contemporary cities.

It seems therefore that, the urban characteristics, such as geometry and built materials, affect the urban microclimate and the comfort conditions at the city center on the pedestrians' level. Thermal environment of urban spaces plays a great role on the quality of life in a city. Downgrading of urban microclimate due to unplanned construction of built forms which is largely the outcome of uncontrolled urbanization is a major concern in many urban centers. So, it is becoming difficult to ignore the unfavorable impact of built forms on urban microclimate, as uncomfortable urban microclimate affects the urban life on outdoor spaces. 
Table 6. Correlation coefficients $\rho$ between $T_{\text {air }}$ at pedestrians' level $(1.5 \mathrm{~m})$ and $T_{\text {surf }}$

\begin{tabular}{|c|c|c|c|c|c|c|c|c|c|}
\hline & & \multicolumn{8}{|c|}{$\rho_{\text {(Tsurf-Tair, } 1.5 \mathrm{~m})}$} \\
\hline & & $\begin{array}{l}\text { Ground } \\
\text { floor }\end{array}$ & $\begin{array}{l}1^{\text {st }} \\
\text { floor }\end{array}$ & $\begin{array}{l}2^{\text {nd }} \\
\text { floor }\end{array}$ & $\begin{array}{l}3^{\text {rd }} \\
\text { floor }\end{array}$ & $\begin{array}{l}4^{\text {th }} \\
\text { floor }\end{array}$ & $\begin{array}{l}5^{\text {th }} \\
\text { floor }\end{array}$ & $\begin{array}{l}6^{\text {th }} \\
\text { floor }\end{array}$ & $\begin{array}{l}7^{\text {th }} \\
\text { floor }\end{array}$ \\
\hline \multirow{3}{*}{ West-S } & May & 0,864 & 0,732 & 0,579 & 0,688 & 0,643 & 0,625 & 0,639 & \\
\hline & July & 0,761 & 0,668 & 0,298 & 0,311 & 0,024 & 0,208 & 0,302 & \\
\hline & August & 0,891 & 0,891 & 0,817 & 0,853 & 0,855 & 0,804 & 0,836 & \\
\hline \multirow{3}{*}{ West-N } & May & 0,898 & 0,752 & 0,673 & 0,739 & 0,739 & 0,684 & & \\
\hline & July & 0,684 & 0,720 & 0,710 & 0,715 & 0,766 & 0,785 & & \\
\hline & August & 0,847 & 0,774 & 0,789 & 0,845 & 0,833 & 0,815 & & \\
\hline \multirow{3}{*}{ North-E } & May & & & & & & & & \\
\hline & July & 0,724 & 0,670 & 0,637 & 0,668 & 0,559 & & & \\
\hline & August & 0,897 & 0,734 & 0,710 & 0,797 & 0,829 & & & \\
\hline \multirow{3}{*}{ North-W } & May & & & & & & & & \\
\hline & July & 0,722 & 0,390 & 0,285 & 0,271 & 0,314 & $-0,181$ & & \\
\hline & August & 0,747 & 0,610 & 0,365 & 0,279 & 0,696 & 0,281 & & \\
\hline \multirow{3}{*}{ East-S } & May & & & & & & & & \\
\hline & July & 0,624 & 0,676 & & & & & & \\
\hline & August & 0,784 & 0,711 & & & & & & \\
\hline \multirow{3}{*}{ East-N } & May & 0,757 & 0,573 & 0,705 & 0,760 & 0,638 & & & \\
\hline & July & 0,618 & 0,720 & 0,720 & 0,713 & 0,738 & & & \\
\hline & August & 0,829 & 0,791 & 0,802 & 0,795 & 0,835 & & & \\
\hline \multirow{3}{*}{ South-E } & May & & & & & & & & \\
\hline & July & 0,691 & 0,757 & & & & & & \\
\hline & August & 0,767 & 0,741 & & & & & & \\
\hline \multirow{3}{*}{ South-W } & May & & 0,463 & 0,557 & 0,260 & 0,407 & 0,366 & 0,465 & \\
\hline & July & 0,076 & $-0,279$ & $-0,627$ & $-0,579$ & $-0,462$ & $-0,458$ & $-0,344$ & \\
\hline & August & 0,701 & 0,438 & 0,260 & 0,326 & 0,280 & 0,335 & 0,362 & \\
\hline
\end{tabular}

Also, the correlation between the surface temperature on different heights and the air temperature on the corresponding measurement height is estimated eg. For the measurement point 22Ag2 which refers to the $6^{\text {th }}$ floor of a specific building, the $\rho$ between (Tsurf) ${ }_{6 \text { th }}$ and (Tair) 22Ag2 $_{2}$ is calculated. In Table 10, the most significant correlations are shown. The correlation coefficients are not so considerable on higher levels, in the upper boundary layer of the study urban area $\left(6^{\text {th }}\right.$ floor, $22 \mathrm{~m}$ height) as on pedestrians' level (ground and $1 \mathrm{sr}$ floor, $1.5 \mathrm{~m}$ height). Therefore, the effect of built environment in urban microclimate is more significant on lower level inside the urban canyons.

Table 7. Correlation coefficients $\rho$, between $\mathrm{T}_{\text {air }}$ and $\mathrm{T}_{\text {surf }}$ on upper boundary layer of the study area.

\begin{tabular}{ccc}
\hline & Correlation coefficient & $\boldsymbol{\rho}$ \\
\hline South-W & $(\text { Tsurf })_{\text {th- }}$-(Tair) $)_{22 \mathrm{Ag} 2}$ & 0,530 \\
\hline East-S & (Tsurf $_{6 \mathrm{th}}$-(Tair $)_{22 \mathrm{M} 1}$ & 0,656 \\
\hline
\end{tabular}

\subsection{Wind speed}

The Wind Speed in the urban area and in the suburban area for each month is described in the diagrams below (Fig. 9). For each hour, the average value from the total measurement data of each month has been calculated. The left diagram includes the Wind Speed (WS) of suburban and urban stations, while the right includes only the urban MP. For all months, the WS in the airport is higher than in the MP inside the urban area. 


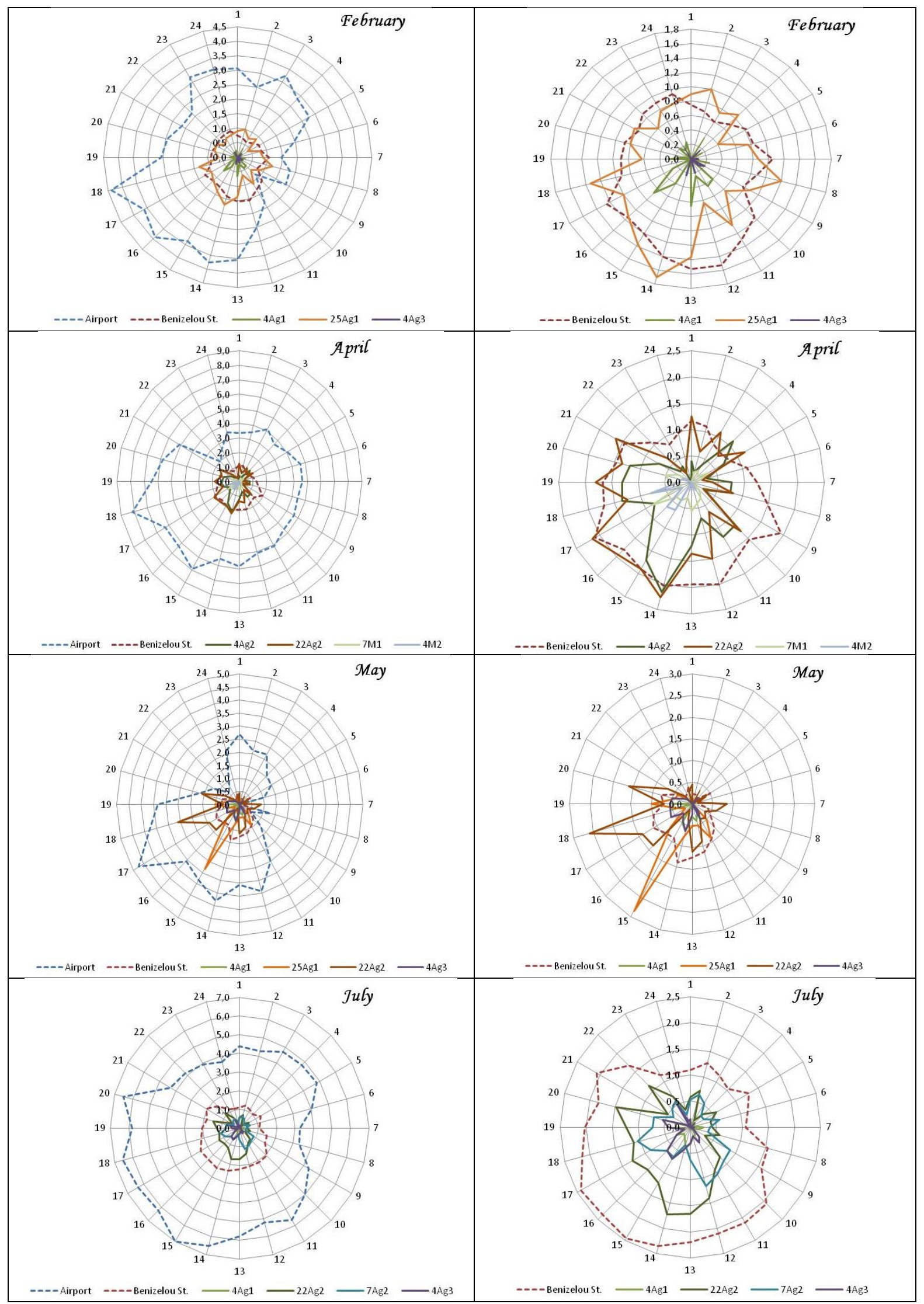

Figure 9. Wind Speed in the suburban area (Airport) and at the measurement points in the urban center. 
The wind speed differences between the suburban, urban and the measurement points have been calculated for each month. In Table 6 the maximum and the mean WS difference are given. The maximum difference between suburban area and the measurement points inside the study urban area ranges from 4,4 m sec${ }^{-1}$ in February until to $8,1 \mathrm{~m} \mathrm{sec}^{-1}$ in April. The mean difference, calculated from all measurement data for each month separately, ranging from $1.9 \mathrm{~m} \mathrm{sec}^{-1}$ to $4.7 \mathrm{~m} \mathrm{sec}^{-1}$.

Table 8. Differences of Wind Speed between suburban area and urban center

\begin{tabular}{lcc}
\hline Month & Maximum Difference & Mean Difference \\
\hline February & 4,4 & 1,9 \\
\hline April & 8,1 & 4,4 \\
\hline May & 4,7 & 1,9 \\
\hline June & 4,4 & 2,0 \\
\hline July & 7,0 & 4,7 \\
\hline
\end{tabular}

Also, the Wind Speed differences between measurement points which are located at different heights, in the same point along the streets and between the measurement points which are located at the same height but in different points along the streets, are calculated. According to the Table 7 the Wind Speed is greater on higher measurement points than in lower levels. The average difference between the measurement points which are located at a height of $25 \mathrm{~m}$ and at $4 \mathrm{~m}$ is about $0.5 \mathrm{~m} \mathrm{sec}^{-1}-0.7 \mathrm{~m} \mathrm{sec} \mathrm{c}^{-1}$. The maximum difference is about $1.7 \mathrm{~m} \mathrm{sec}^{-1}$.

In Agias Sofias Street, in low level height of $4 \mathrm{~m}$, the WS in February is greater inside the narrow urban canyon (in the measurement point 4Ag1) than at the larger width street (measurement point 4Ag3). The reverse phenomenon is observed during summer months.

Also, the WS differences between different measurement points in the same height along the urban canyon are greater than between different heights.

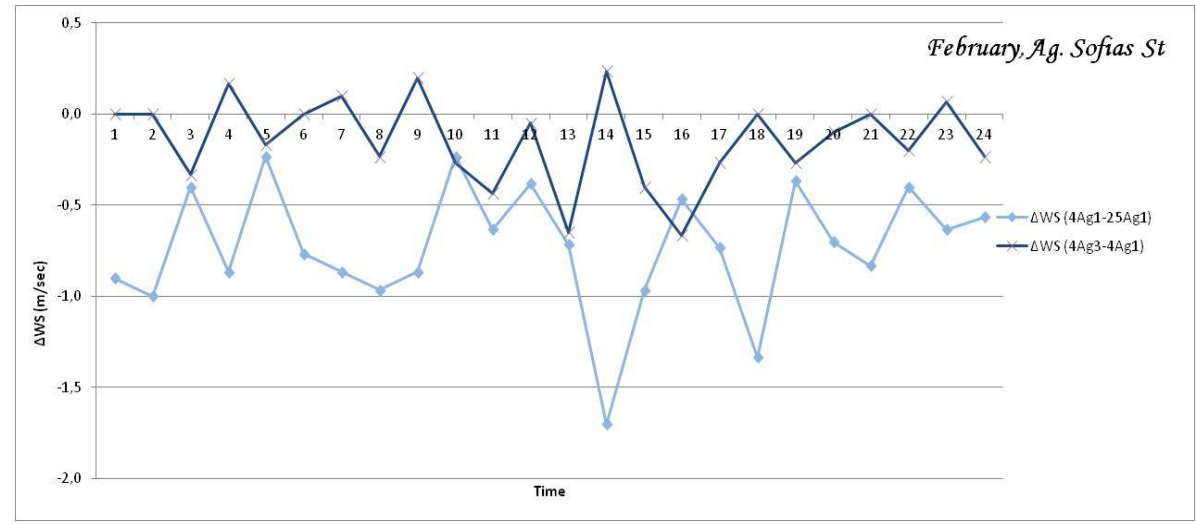

Figure 10. Wind Speed Differences at the urban center, February

Regarding the vertical road Mitropoleos street, the WS in lower height is greater near the crossways, at the end of the urban canyon, than along the road $(7 \mathrm{M} 3>4 \mathrm{M} 2)$. 


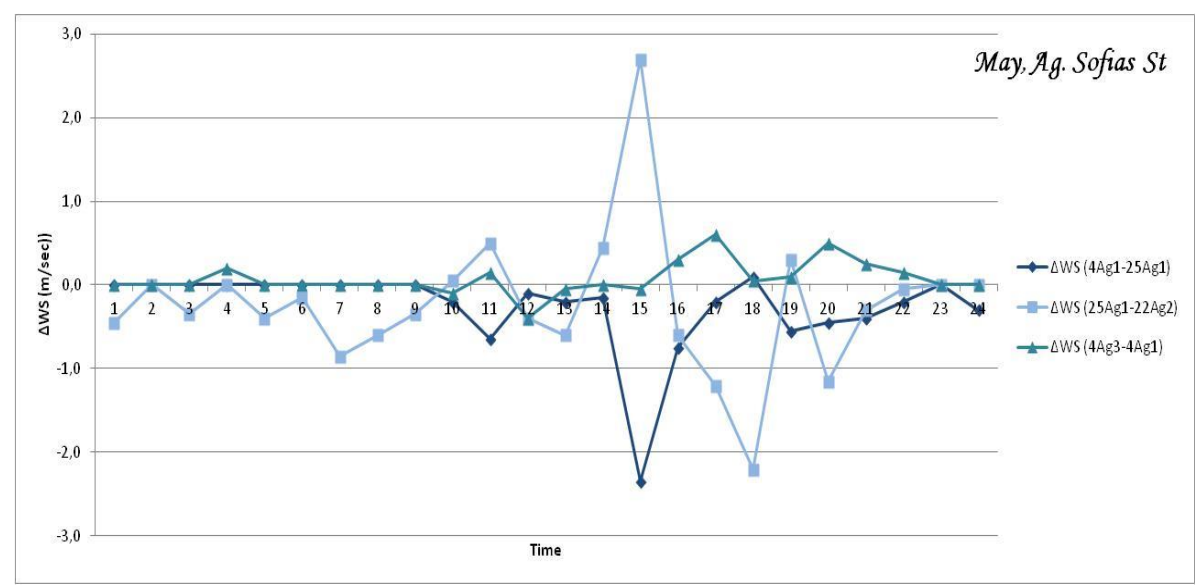

Figure 11. Wind Speed Differences in the urban center, May

Table 9. Wind Speed comparison between different measurement points, for each month

\begin{tabular}{cccc}
\hline Month & Comparison & Mean difference & Maximum difference \\
\hline February & 25Ag1>4Ag1 & $0.7 \mathrm{~m} \mathrm{sec}^{-1}$ & $1.7 \mathrm{~m} \mathrm{sec}^{-1}$ \\
\hline April & $4 \mathrm{Ag} 1>4 \mathrm{Ag3}$ & $0.3 \mathrm{~m} \mathrm{sec}^{-1}$ & $0.7 \mathrm{~m} \mathrm{sec}^{-1}$ \\
\hline May & $\mathbf{2 2 A g 2 > 4 A g 2}$ & $0.5 \mathrm{~m} \mathrm{sec}^{-1}$ & $1.4 \mathrm{~m} \mathrm{sec}^{-1}$ \\
\hline & $\mathbf{7 M 3 > 4 M 2}$ & $0.4 \mathrm{~m} \mathrm{sec}^{-1}$ & $0.8 \mathrm{~m} \mathrm{sec}^{-1}$ \\
\hline June & $\mathbf{2 5 A g 1 > 4 A g 1}$ & $0.5 \mathrm{~m} \mathrm{sec}^{-1}$ & $0.6 \mathrm{~m} \mathrm{sec}^{-1}$ \\
\hline July & $\mathbf{2 2 A g 2 > 2 5 A g 1}$ & $0.6 \mathrm{~m} \mathrm{sec}^{-1}$ & $2.2 \mathrm{~m} \mathrm{sec}^{-1}$ \\
\hline $\mathbf{2 2 A g 2}$ & & $0.5 \mathrm{~m} \mathrm{sec}^{-1}$
\end{tabular}

In the diagrams below, the percentage of wind speed differences from the suburban area to the urban area are presented. For the comparison, two values of wind speed were selected. One of the suburban area and one of the study area. The measurement point with the maximum wind speed was selected from the urban center.

In February, the mean percentage of wind speed change between the suburban area and the 25Ag1 measurement point is about $35.33 \%$ to $85.27 \%$.

In April, the percentage of wind speed reduction in 22Ag2, ranging from $22.86 \%$ to $100 \%$. Change $100 \%$ occurs when the wind speed in the urban center is zero.

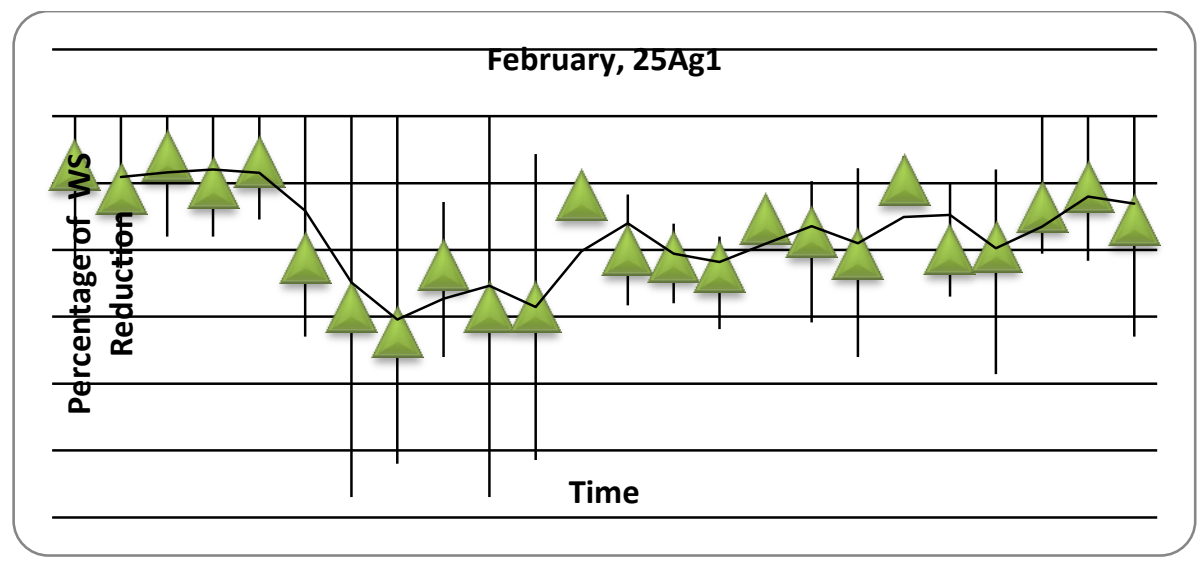

Figure 12. Percentage of Wind Speed Reduction in February 


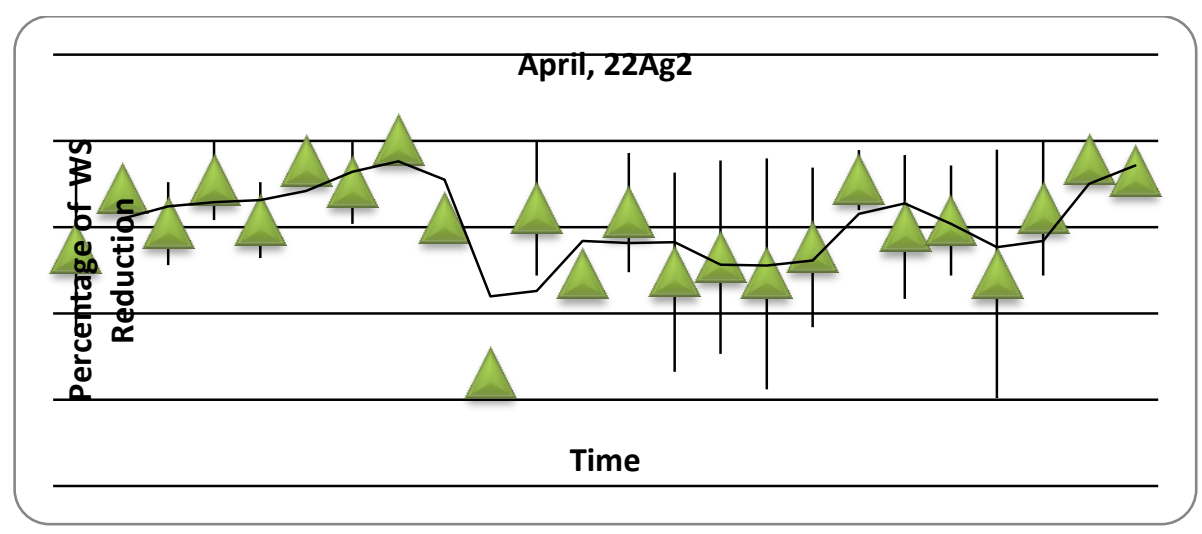

Figure 13. Percentage of Wind Speed Reduction in April

In May two points are examinated, at $25 \mathrm{~m}$ and $22 \mathrm{~m}$ height, which are located at different positions along the urban canyon. For the measurement point $25 \mathrm{Ag} 1$, which is located inside the urban canyon of Agias Sofias Street, the percentage of wind speed change fluctuates from $53.71 \%$ to $100 \%$, while for the $22 \mathrm{Ag} 2$ (near to the crossway) it fluctuates from $43.31 \%$.

In June, the rate of wind speed reduction from the suburban to the urban center, in 22Ag2 measurement point, ranging from $50-100 \%$. The time period from 20:00 to 23:00 is an exception, where the percentage reduction is less.

In July, the percentage of wind speed reduction in $4 \mathrm{Ag} 3$ is height during the 24-hour and it ranges from $80.36 \%$ to $100 \%$.

\subsection{Wind direction}

The monthly Wind Direction for each measurement point is presented below. The percentage that each wind direction appears is calculated in Table 10.

The Wind Direction changes from the suburban area (Airport) to the urban area. Specifically, the direction inside the urban center is affected according the height of the measurement point, the month and the geometric characteristic of the street's morphology. For example, in February the prevailing direction inside the urban canyon ( $\mathrm{Ag} 1)$ is northern, while at the measurement point in the wider part of the street (Ag3) is eastern. In April, in the same position along the street (Ag2), the prevailing direction at $4 \mathrm{~m}$ height is south-western, while in the higher level of $22 \mathrm{~m}$ it is western. Also, it is observed that the street's orientation affects the WD. In June, the Wind Directions in the same height in Agias Sofias street and in the vertical street of Mitropoleos, are different.

Table 10. Wind direction appearance (percentage) in the total of the measurement data

\begin{tabular}{|c|c|c|c|c|c|c|c|c|c|c|c|c|c|c|c|c|c|c|c|c|}
\hline \multirow[t]{2}{*}{$\begin{array}{c}\text { Wind } \\
\text { Direction }\end{array}$} & \multicolumn{4}{|c|}{$\begin{array}{c}\text { Percentage \% } \\
\text { February }\end{array}$} & \multicolumn{4}{|c|}{$\begin{array}{c}\text { Percentage \% } \\
\text { April }\end{array}$} & \multicolumn{4}{|c|}{$\begin{array}{c}\text { Percentage \% } \\
\text { May }\end{array}$} & \multicolumn{4}{|c|}{$\begin{array}{c}\text { Percentage \% } \\
\text { June }\end{array}$} & \multicolumn{4}{|c|}{$\begin{array}{c}\text { Percentage \% } \\
\text { July }\end{array}$} \\
\hline & Airport & $4 \mathrm{Ag} 1$ & 25Ag1 & $4 \mathrm{Ag} 3$ & Airport & 4Ag2 & 22Ag2 & 7M1 & Airport & 25Ag1 & 22Ag2 & $4 \mathrm{Ag} 3$ & Airport & 22Ag2 & 22M1 & $7 \mathrm{MB}$ & Airport & $4 \mathrm{Ag} 1$ & 22Ag2 & $4 \mathrm{Ag3}$ \\
\hline $\mathbf{N}$ & 20,6 & 100 & 100 & & 30,4 & 2,1 & & 2,1 & & 2,1 & 2,1 & & & & & 2,1 & 38,8 & & 1,1 & \\
\hline NE & & & & & & & & & & & & 2,1 & & & 2,1 & & & & & 98,9 \\
\hline $\mathbf{E}$ & 30,9 & & & 98,6 & 17,9 & & & & 32,6 & & & & 38,1 & & 95,7 & & 5,8 & 53,7 & & \\
\hline S E & 2,9 & & & & 3,6 & & & & 7 & & & 97,9 & 2,4 & & & & & 45,3 & & \\
\hline $\mathbf{S}$ & 1,5 & & & & 28,6 & & & & 27,9 & & 97,9 & & 21,4 & & & & 2,9 & & & \\
\hline S W & 23,5 & & & & 14,3 & 97,9 & & & 14 & 95,7 & & & 0 & & & & 26,2 & & & \\
\hline $\mathbf{W}$ & 20,6 & & & & 5,4 & & 100 & 95,7 & 18,6 & 2,1 & & & 38,1 & 100 & & & 26,2 & & 98,9 & \\
\hline N W & & & & 1,4 & & & & 2,1 & & & & & & & 2,1 & 97,9 & & 1,1 & & 1,1 \\
\hline
\end{tabular}

\section{Conclusions}

The morpholological characteristics of urban geometry, the orientation, the season, the materials are important factors that influence the surface temperatures and the microclimatic parameters in the urban centers and affect conditions inside the urban canyons. 
The present study has investigated the temperature fluctuation of vertical surfaces and the microclimatic conditions during $12 \mathrm{~h}$ and $24 \mathrm{~h}$ basis, in different periods. The study area is located in the urban center of Thessaloniki which is regarded as a location with typical geometrical characteristic of the contemporary Greek cities. The data analysis has led to the following observations:

The time period that the maximum surface temperature is observed, correlates with the orientation, the height of the opposite buildings and shadowing and the microclimatic conditions.

It is concluded that, in the streets which are allocated in the axis North-South, the maximum surface temperatures at the west side of the road, are observed during morning time, while at the east side of the road they are observed at afternoon time. The higher surface temperatures are measured at the western side. In the axis West-East, the maximum $T_{\text {surf }}$ are reached mainly at afternoon. The northern or southern side of the road is inconsiderable, regarding the thermal behavior of the vertical surfaces. In the West Street the maximum surfaces temperatures are noticed at $14: 00-16: 00 \mathrm{pm}$ and in the East Street later, at 17:00-18:00pm.

Also, the location of the building inside the western urban canyon and the distance from the crossway influence the surface temperature between the floors. The maximum temperature in the buildings near the crossway is observed at the first floors during the $12 \mathrm{~h}$ of measurement procedures. At the buildings inside the urban canyon the first floors have higher temperature at morning, while in the afternoon higher temperatures are observed in the last floors. At the roads with lower buildings at one side, the first floors have the maximum temperature during all the 12 hours of observation.

Regarding the air temperatures at the two studied urban canyons, it has been observed that there are differences according to the height, the location along the canyon, the distance of the crossway, the time and the season. During all the measurements, the air temperatures are higher at the $4-7 \mathrm{~m}$ than at the 22-25m, except from two hours near the sunset (15:00-17:00 for February, 18:00-20:00 for April and 19:00-21:00 for May). So, the air temperature is higher at the lowest layer of the urban canyon, close to the pedestrians' level.

The air temperature inside the canyon, at the lowest layer, is higher at the building near to the crossway than at the buildings in the middle and in the end of the canyon, during the day. Also, the air temperature at the end of the canyon is higher than in the middle, except for night hours. Moreover, the $T_{\text {air }}$ is higher at the wider parts of the roads than at the buildings inside to the narrow part of urban canyon. The solar radiation and the shadowing of the opposite buildings are playing significant role to the configuration of microclimatic condition, $\mathrm{T}_{\text {air. }}$.

The correlation coefficients between $T_{\text {air }}$ at pedestrians' level $(1.5 \mathrm{~m})$ and $\mathrm{T}_{\text {surf }}$ of each floor are analyzed. The correlation of these two parameters is higher between the air temperature on $1.5 \mathrm{~m}$ height and surface temperature of the ground and first floor. The maximum coefficient values have appeared in the urban canyons, which are characterized by high buildings on both sides of the road and narrow street. So, an increasing of the vertical surface temperature on ground and first floor has appeared when the air temperature at pedestrians' level is increasing. On higher levels, the correlation coefficients are not so significant. The effect of built environment in the urban microclimate is more important on pedestrians' level than in the upper boundary layer of the urban area.

The Wind Speed, according to the study, is greater inside to the narrow urban canyon, at the low level of $4 \mathrm{~m}$ height, during winter (February), than in the wider street. The reverse phenomenon is observed during summer months. The WS differences between different measurement points at the same height along the urban canyon are greater than between different heights. Also, the WS in lower heights is higher near the crossways, at the end of the urban canyon, than inside the road.

The Wind Direction changes from the suburban area to the urban center. The prevailing WD is modified between different months and measurement points. It is conducted from the analysis that the WD is affected according the measurement height and the position along the urban canyon. Different directions are observed between measurement points at the same height which are located in different positions along the street or between measurement points on different heights. 
Concluding, the urban morphology of the built environment is the important factor that affects the microclimatic and living conditions inside the urban centers. The investigation and research on these parameters can help us towards a better and sustainable design and the rehabilitation of contemporary cities.

\section{Acknowledgement}

The authors wish to extend a sincere thanks to the Environmental Department of Municipality of Thessaloniki for the weather data for Benizelou Station and the Hellenic National Meteorological Service for the data from the Airport of Thessaloniki.

\section{References}

Andreou E. and Axarli K. (2012), Investigation of urban canyon microclimate in traditional and contemporary environment. Experimental investigation and parametric analysis, Renewable Energy, 43, 354-363.

Erell E., Pearlmutter D. and Williamson T. (2011), Urban microclimate Designing the spaces between buildings, Earthscan, London, pp.15-20

Gartland L. (2008), Heat Island Understanding and Mitigating Heat in Urban Areas, Earthscan, London, pp. 27-28.

Giannaros T.M., Melas D. and Kontogianni P. (2010), An Observational Study of the Urban Heat Island in the Greater Thessaloniki Area: Preliminary Results and Development of a Forecasting Service, AIP Conf. Proc., Volume 1203, pp. 991-996.

Kantzioura A. Kosmopoulos P. and Zoras S., (2012), Urban surface temperature and microclimate measurements in Thessaloniki, Energy and Buildings, 44, 63-72.

Kosmopoulos P., (Ed.), 2008, Building, Energy and Environment, University Studio Press, Thessaloniki

Mihalakakou G., Santamouris M., Papanikolaou N., Cartalis C. and Tsangrassoulis A. (2004), Simulation of the urban heat island phenomenon in Mediterranean climates, Pure and Applied Geophysics, 161, 429-451.

Santamouris M. (Ed.), 2001, Energy and climate in the urban built environment, James\&James, London, pp. 6-7.

Stathopoulou M., Cartalis C. and Keramitsoglou I., (2004), Mapping micro-urban heat islands using NOAA/AVHRR images and CORINE Land Cover: an application to coastal cities of Greece, International Journal of Remote Sensing, 25(12), $2301-2316$. 